\begin{tabular}{r|l} 
HPSCONF & $\begin{array}{l}\text { 8th International Conference on } \\
\text { Humanities, Psychology and Social Science } \\
\text { October } 19-21,2018 \text { Munich, Germany }\end{array}$
\end{tabular}

\title{
Migration exchanges of Russian regions with the CIS-countries and potential of transit movements
}

\author{
Svetlana Maximova ${ }^{1, *}$, Oksana Noyanzina ${ }^{2,}$ Daria Omelchenko ${ }^{3,}$ Maxim Maximov $^{4}$ \\ ${ }^{1}$ Department of Sociology, Altai State University, Russia \\ ${ }^{2}$ Department of Sociology, Altai State University, Russia \\ ${ }^{3}$ Department of Sociology, Altai State University, Russia \\ ${ }^{3}$ Department of Sociology, Altai State University, Russia
}

\begin{abstract}
Article presents results of statistical analysis about indexes of migration growth in a result of migration exchange of Russian regions with the CIS countries. Subjects of the Russian Federation were considered from the point of view of attractiveness to migrants, bases for analysis are open data of statistical bulletins by the Rosstat. A special attention is paid to the distribution of the most popular migration roots form the CIS countries in the Russian Federation; possible transit regions were specified. Paper specifies groups of subjects, having different attractiveness for migrants. Authors conclude about poor ability of Russian migration statistics to reflect real migration movements of migrants, because a part of migrants hide real purposes of their visit and wish to make easier the stay in the Russian Federation or sometimes plan to use illegal roots and resources of migration to the Western (or other) countries because the absence of opportunity of legal crossing through strictly protected or nontransparent borders. Statistics of the transit covers only those migrants, who are sure in the final point of movement and legally move through the transit stages, or those, who are in temporary migration (tourism, education, work of private visits) and move in transit in the Russian Federation. There is a tendency of meagre flows of migrants from the CIS countries to ethnic republics of Russia. The criteria of regional differences "Russian core - Ethnic regions" determines peculiarities of migration processes. The popular roots of migrants across the Russia testify about ethnic character of migration of citizens from the CIS countries: stable and considerable in numbers from certain country to certain regions, and presence of agency
\end{abstract}




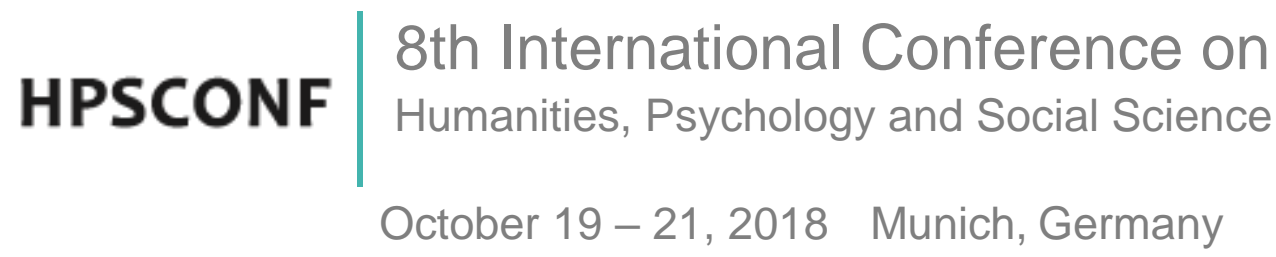

networks on promotion of transit migration movements basing on diaspora networks in country of temporary residence, including criminal.

Keywords: migration, transit migrants, movement, migration exchange, Russian regions, the CIS-countries, potential of transit.

\section{Background}

Transit migration is a synthetic concept, combining the notions of transit and migration [1], it is extremely dynamic because it is scientifically diffused and ideologically and politically loaded. The given concept refers to certain forms of probably temporary migration and migrants, who move from one country to another, as intentionally as forcibly in a result change in life conditions, new stimulus of threats. In a broad sense, transit migration involves real and imaginary movements and trips for long distances and periods. Such movements could be dangerous and may change own directions.

Transit migration often confines with ethnic migrations. Therefore, some researches [2] speak about interdependence between transnational ethnic communities, providing safe corridors for further movements, and illegal agents help migrants to choose short roots or to cross difficult steps of the way: cross national borders, prepare the stops in transit countries. And at last, migrants could 'stuck' in intermedia countries because of the lack of money, inability to cross the border or exploitation by 'ethnic agents'. Different aspects of such movements - a way out from the country of origin, entry and temporary stay in transit country, exit and entry to the country of destination could be as legal as illegal, as could be legal or illegal some portions of the root [3].

Geography of transit migration may be identified through transit zones, such as the CIS countries, the Russian Federation, the Ukraine, the Azerbaijan, the Turkey, the Cyprus, and the Balkans. Resume of the International conference «(Irregular) Transit migration in the European Space» (Istanbul, 2008) [4] allocates six types of countries, involved in transit: courtiers of origin; countries - initial roots (for example, the Russia, the Yemen, the Mauritania, the Senegal, and the Mali); countries - trampling to the Europe (for example, the Ukraine, the Serbia, the Turkey, the Libya, the Cape Verde, and the Morocco); the first country of destination; transit countries on the root; country of final destination (as a rule, the European countries or the Northern American countries).

However, we should not to consider the given typology as a dogma. Dynamic nature of the migration patterns (illegal, especially) let us consider separate countries as 'a point of entry' 
for one migrant and 'a point of destination' for the other. Furthermore, characteristics of migration often change, and transit countries become countries of destination (as occurred in the Spain or the Italy). Representations of migrants about the 'point of destination' may also change with the experience of movements after relocation, and the country, initially seen as the country of temporary stay, becomes the country of permanent residence. It illustrates the changes in migrant's perception and their attitudes. Because of changing political conditions, enforcement of laws and other administrative measures, migration strategies are also change: migration streams reduce and diminish in points with hard police regimes; new roots and opportunities emerge; new points of destination and exit on these roots emerge too.

Summarizing a number of scientific publications, we may determine groups of suppositions about migrants in transit:

they are migrants from countries with low income level to the courtiers with average incomes, seeking for the high income countries; they are migrants not only for the transit EU countries, but other transit countries on the way to final destination.

The Russian Federation, such as in the Europe, the processes of transit migration escalated in the middle of 1990s with the opening of borders for the CIS migrants, who used Russia as the country of transit to the Europe. During that time, the activity of different agents, promoting to illegal migration out of the country. Russia became convenient channel for European movements not only for migrants from the Central Asia, but from the China and the Africa. Trofimova [5] associate the Russian Federation as a country of transit with its geography (including a shared land boundary with the EU), porous borders with the CIS countries, week entry control for foreign citizens and their stay in Russia, and 'absence of real institutional management tools for migration processes', high level of corruption, distribution of informal labor practices, and network interactions between ethnic diaspora groups. In particular, in Russia there are almost unlimited opportunities of participation in the shadow economy [6], and, therefore, a wide opportunities to earn for the next step of migration.

One more aspect of the given phenomenon is the border asymmetry of Russian borders, i.e. rather easy entry to the territory of the country and inability to leave it because strictly protected boundaries of the bordering developed countries. Thus, illegal migrants stay in Russia for a long time, but do not want to be the permanent residents of the country or make their stay legal, demonstrate unwillingness to integrate and, in fact, 'a neglect to the country' $[7,8]$.

All the abovementioned indicates transit as very movable concept, rather complicated object for sociological research, weakly determined and operationalized, having prejudices and deeply politicized [9]. But, as a complex notion, the phenomenon of transit need in further discussion 


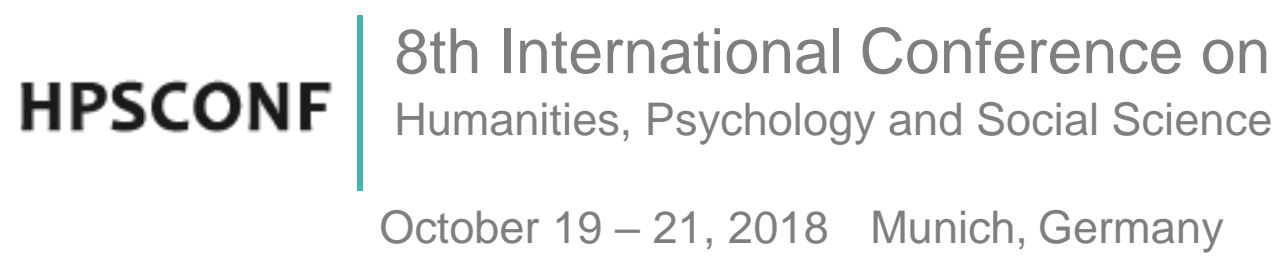

and study, research about types of migration and categories of migrants, influence of political discourse to the transit, understanding of the transit in whole [11].

\section{Methods}

The goal of the article is consideration of general migration trends in the Russian Federation from the positions of the evaluation of the potential of the transit of migrants from the CIS countries, and general directions of transit movements, also. Bases for further analysis are open data of statistical bulletins by the Rosstat, in particular, "Population and migration in the Russian Federation", "Natural movement of population of the Russian Federation" for the period of 2016 - 2017, and data by the All-Russian Population Census of 2010, also [12 - 14]. Data of contemporary migration statistics testify, that only in 2016 about $3.0 \%$ of people in the territory of Russian Federation moved as inside as outside the country. Mobility of population considerably increased starting from 2011, more than 61.0\% (from 2103304 persons who entered the country in 2010 to 3415055 of people in 2015) and intensified, further. At the same time for the period of 2006 - 2017 in Russia fixed the migration growth due to the foreign citizens, which increased twice for the decade: from 132219 of persons in 2006 to 261948 of persons in 2016. Only in 2008 a migration growth did not showed the tendency of the growth. The situation describes increasing internal and external mobility of population, which moves between regions. So, the difficulties, accompanying the movements, became considered as not important in the face of economical profits of migration. Rationally speaking, we supposed the expansion and formation of new types of migration movements, distribution of migration strategies, vital plans, corresponding attitudes and intentions. Paper presents analysis of data (2006 - 2016) about migration inflow and outflow from the CIS countries, structure of distribution of the CIS migrants throughput Russian regions, indexes of migration growth, structure of migration outflow to the CIS and other foreign countries, including the Europe.

\section{Results}

The results section is the most important part of the abstract and nothing should compromise its range and quality. The results section should therefore be the longest part of the abstract and should contain as much detail about the findings as the journal word count permits. Almost each the CIS country for the period of last years slightly, but increased own 'donorship' to the Russian Federation. In the period of 2008 - 2011, the number of migration inflow and outflow had negative dynamics, such as the in-country mobility, and coincided with crisis in the country's economy (economic crisis of 2008 and the period the way out of it). Starting from 2011 the part of enter and exit foreign migrations started to grow. 
In 200654061 of people moved out of Russia abroad, and three times more - entered Russia 186380 of people, in 2012122751 of people moved out of the country, and entered -417681 of foreigners, in 2016576158 of people come to Russia from foreign countries and 313210 of people moved abroad. In numbers, the totality of people, who entered the Russian Federation for the all considered period was the greater than the number of those, who moved out of Russia. At the same time, the number as the foreign migrants as the native immigrants rebounded ahead: in 2011 statistics fixed a rapid growth of foreign migrants from 191656 of persons in 2010 up to 356535 of persons in 2011. Probably, the situation with the foreign inflow (as the further analysis showed, dominantly from the CIS and Baltic countries) was connected with the change in migration registering and law condition of foreigners in Russia in 2011.

These amendments created favorable conditions for transit migrations, first, let migrants during seven days without registration (or, during the longer time) and without special sanctions of the state to reside the country, move to more economically favorable regions of the country. The conclusion is supported by the growth in number of citizens, moved out of the country in 2012: from 36774 of people in 2011 to 122751 of people in 2012. Further, the migration exchange of Russia with foreign countries increased.

Meaning the goal of the paper, connected with the understanding the migrant's trajectories, including the CIS migrants, let us specify the following. During the last three years, the part of migrants form the CIS countries has remained relatively static, but in the period from 2003 to 2013 - slightly increased from 271623 of persons in 2008 (12.3\% of all movements) to 422 738 or persons in 2013 (9.7\% of all movements). In $2014-2016$, the number of migrants from the CIS countries annually consisted more than 500000 of persons (10.9\% of all population movements in 2016). However, in 2011 the part of foreign migrants in total movements of Russian population increased in absolute numbers 3.5 times (from 12590 in 2010 to 45986 in 2011, in 201663385 of foreign citizens came to Russia from the far abroad (1.3\% of all population movements).

Nowadays, according to migration statistics by subjects of the Russian Federation, in 2016 Russian migration growth from the CIS countries was 255293 of people and other foreign countries - 6655 of people. For comparison, in 2008 the internal migration growth from the CIS courtiers was 244767 or persons, far abroad - - 2661 of persons.

Thus, basing the analysis of indexes of migration exchange between Russian regions and the CIS countries, we revealed groups of subjects, having different attractiveness for migrants in 2016: 
the first group consisted of four subjects of the Russia Federation, here the indexes of migration growth have highest values and are higher than 12000 of people: the Moscow oblast, the Tyumen oblast, the Krasnodarsky krai, and Novisibirskaya oblast; the second group - regions, there the migration growth in absolute numbers consisted from 5 to 10 thousands of people: the Kurskaya oblast, the Voronezhskaya oblast, the Republic Crimea, the Khanty-Mansi Autonomous Area, the Kaluzhskaya oblast, and the Mordovia, the Rostovskaya, Belgorodskaya, Chelyabinskaya oblast, the Moscow, the Kemerovo oblast, the Tulskaya oblast, the Krasnoyarsky krai, the Lipetskaya oblast, the Kaliningradskaya oblast, Samarskaya oblast, the Sevastopol, and the Saratovskaya oblast; the third group - subjects of the Russian Federation with the migration growth from one to 4.5 thousands of people: the Omsk oblast, the Leningradskaya oblast, the Orenburg oblast, the Volgogradskaya oblast, the Stavropolsky krai, the Khabarovsky krai, the Ulyanovskaya oblast, the Tatarstan Republic, the Yaroslavskaya oblast, Bryanskaya oblast, the Primorsky krai, the Ryszanskaya oblast, the Nizhegorodskaya oblast, the Penzenskaya oblast, the Saint-Petersburg, the Astrahanskaya oblast, the Vladimirskaya oblast, the Novgorodskaya oblast, the Altai krai, the Orlovskaya oblast, the Tchuvashiya Republic, the Kurganskaya oblast, the Yamalo-Nentsi Autonomous Area, the Smolenskaya oblast, the Pskovskaya oblast, the Permsky krai, the Adygeya Republic, and the Magadanskaya oblast; the fourth group consists of regions with the migration growth lower that one thousand of people: the Arkhangelskaya oblast, the Udmurtiya Republic, the Amurskaya oblast, the Murmanskaya oblast, the Sakhalinskaya oblast, the Ivanovskaya oblast, the Komi Republic, the Kamchatsky krai, the Yakut Republic, the Buryat Republic, the Omskaya oblast, the Trans-Baikal krai, the Karel Republic, the Northern Ossetia, the Kabardino-Balkariya, the Dagestan, the Kostromskaya oblast, the Mary El, the Kirovskaya oblast, the Chechnya, the

Altai Republic, the Tyva Republic, the Chukotka Autonomous Area, the Nentsi Autonomous Area, the Jewish Autonomous Area, the Karachaevo-Cherkessiya, and the Ingushetia Republic and, finally, the firth group of regions with negative migration growth of the CIS citizens consists of the Kalmykia Republic, the Bashkir Republic, and the Tambovskaya oblast.

In the one group of regions, we included subjects of Russian Federation, accepting similar in numbers migration flows from the CIS countries, but in the group, we see regions with different center-periphery status, level of social-economic development and condition of labor market. Therefore, it is not possible to conclude about unambiguous movement of the 
CIS migrants to 'the West', including transit, or tend to the Russian borderlands in whole. As abovementioned, the quantitative analysis of statistics does not let to conclude about presence, character, qualitative and quantitative parameters of transit migration.

However, as a tendency we may specify a week flows of the CIS migrants to ethnic republics of Russian Federation. Probably, the criteria of regional differences by the axis 'Russian core - ethnic republics' will determine as peculiarities of migration processes as transit practices, also. The conclusion requires for the deeper research of migration trajectories, including qualitative methods.

Unfortunately, nowadays we have access about the country structure of inflow migration only for the period to 2012. In 2012 the huge inflow of migrants was 'provided' by the Uzbekistan - 87902 of persons, much low was the inflow of Ukrainian migrants (49 411 of persons), and from the Kazakhstan (45 506 of persons). The less 'ethnic' groups of migrants came from the Turkmenia (5 442 of persons), the Byelorussia (16 564 of persons), and the Azerbaijan (22 287 or persons).

The geography of 'distribution' of migrants from the CIS countries: to the regions of the Central federal district dominantly moved migrants form the Uzbekistan (25 383), the Ukraine (20 757), and Moldova (14 632); to the Northern-Western federal district - migrants from the Uzbekistan dominantly (21 046); to the Southern federal district from the

Uzbekistan (5 896) and Armenia (5 385); to the Northern-Caucasus federal district - from the Azerbaijan (1 084) and Armenia (3 189); the Privolzhsky federal district - from the

Uzbekistan (16 670), the Tajikistan (8 432), the Kazakhstan (6 358 к) and Armenia (6 209); to the Ural federal district - from the Tajikistan (7 646), the Ukraine (77 022), the Kirgizia (5 844), Kazakhstan (5 615) and Uzbekistan (5 379); to the Siberian federal district came the dominant number of migrants from the CIS countries - citizens of the Kazakhstan (14 641), migrants from Kirgizia (7 272), Tajikistan (6 878), and Uzbekistan (5 895); to the Far East federal district - general floe of the CIS migrants - from the Uzbekistan - 6883 of persons.

It should be noted, that the Ukrainian citizens dominantly moved to the Tyumen oblast (6 368 of persons, $12.9 \%$ of all Ukrainians, who came to Russia), the Moscow oblast (5 524 of persons, 11.2\%), Moscow (4 761 of persons, 9.6\%), and Yamalo-Nentsi Autonomous Area (4 543 of persons, 9.2\%). Migrants form the Uzbekistan moved to the Saint-Petersburg (10 992 of persons, 12.5\%), the Leningradskaya oblast (6 694 of persons, 7.6\%), the Tambov oblast (5 047 of persons, $5.7 \%$ ), the Moscow oblast (4 631 of persons, $5.2 \%$ ), and the Tyumen oblast (4 234 of persons, $4.8 \%)$. Citizens of the Turkmenia - to the Saint-Petersburg $(753,13.8 \%)$ and the Moscow oblast $(708,13.0 \%)$, from the Tajikistan - to the Tyumen oblast $(4693,11.3 \%)$ 
and the Saint-Petersburg ( 3 192, 7.7\%), from the Moldavia - to the Moscow oblast (5 234, $35.8 \%$ ), from the Kirgizia - to the Tyumen oblast ( $3125,9.03 \%$ ) and Novosibirskaya oblast (2 $381,6.9 \%)$, and from the Kazakhstan - to the Novosobirskaya oblast (4 946, 10.9\%) and the Omskaya oblast (3 357, 7.4\%), and the Altai region (2 750, 6.04\%). Migrants from the Byelorussia usually move to the Smolenskaya oblast (4 465 of persons, 2.7\%) or the SaintPetersburg (3 495, 21.1\%), from the Armenia - to the Krasnodarsky krai (2 976, 8.05\%), the Moscow oblast $(2854,7.7 \%)$ or the Stavropol krai $(2777,7.5 \%)$, the Azerbaijan - to the Tyumen oblast (1 870, 8.4\%), the Moscow (1 169, 5.2\%) and the Krasnoyarsky krai (1 083, $4.9 \%)$.

In whole, only three subjects of the Russian Federation are the most popular among migrants from the CIS countries - the Saint-Petersburg, accepted in 201228449 of migrants or $7.8 \%$ of all the CIS migrants, the Tyumen oblast (26 536 of persons, $7.3 \%$ ), and the Moscow oblast (25 503 of persons or $7.0 \%$ of all the CIS migrants).

The registration of foreign citizens and stateless persons in the Russian Federation assumes the indication of the purpose of the visit to the country, and among those are transit. In accordance with Russian legislation, a foreign citizen, entering the country, must fill the migration card and indicate the purpose of stay: work visit, tourism, commercial visit, education, work, private visit, or transit. Part of citizens, who indicated 'transit' character of migration is low and do not increase $2 \%$ among all migrations. As for the country structure of the transit, $1.6 \%$ of all the CIS migrants, $1.6 \%$ of all visitors (343 220 of persons from more than 21 millions) came to Russia with transit reasons: $1.3 \%$ from them are from the Azerbaijan, $1.9 \%$ - the Armenia, $14.8 \%$ - the Byelorussia, 1.8\% - the Kazakhstan, 0.7\% - the Kirgizia, 1.4\% - the Moldova, $0.7 \%$ - the Tajikistan, $0.2 \%$ - the Turkmenia, $0.8 \%$ - the Uzbekistan, $1.5 \%$ - the Ukraine. In total, $0.4 \%$ of foreigners in Russian in 2016 were in transit.

The latest data about migration outflow are in access for the 2012. In 201295572 of persons moved out of Russian Federation, the largest in numbers group of migrants moved to the Uzbekistan (31 559), the Ukraine (12 416), the Kirgizia (10 489), the Tajikistan (10 281) and the Kazakhstan ( 8 843), twice less people moved to the Azerbaijan (4 185), the Moldova (4 949), and to the Armenia (4 980). Conventionally return character of migration (basing on comparisons between migrants, who entered from a certain country, and exited it during the year) may be fixed in the third number of cases.

The presented comparison has incorrect character. We do not know, whether the same migrants from the Ukraine, for example, return to the Ukraine from Russia, or to the Ukraine move other foreign citizens, and what is the duration of their stay in Russia, and which character - transit 


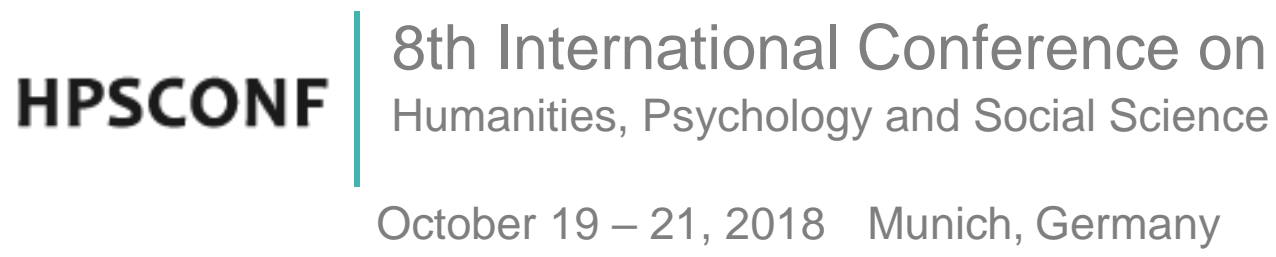

or not - has their migration. However, we may understand the volumes of migrant groups, residing Russia, and conclude about two thirds of the CIS migrants in Russia as about the potential groups of transit - whether desired or realized in the next steps of migration outside the CIS countries.

Basing on statistical analysis of indexes of the migration growth during the migration exchange between Russian and the CIS countries, we may specify the groups of regions with different attractiveness for migrants. Thus, the most popular are only four subjects of the Russian Federation with maximal migration growth higher that 12 thousands of people: the Moscow oblast, the Tyumen oblast, the Krasnodarsky krai and the Novosibirskaya oblast.

Distribution of the most popular roots of migrant's movements in Russia may testify about ethnic character of migrations, first; and presence of the agent's networks, basing on diaspora connections (including criminal) because of huge stable flows of migrants from a certain country.

The registration of foreign citizens and stateless persons in the Russian Federation does not reflect real migration attitudes of moving citizens, because a part of migrants hide own real purposes of the visit, willing to make easier their stay in Russia or planning to use illegal channels or resources because the absence of opportunity to cross strictly protected borders of developed countries, bordering with the Russian Federation. Besides, a considerable part of migrants does not have a short-term plans of further migration and only dream about next steps of the root, has no clear migration strategies or resources for further migration, so, they continue stay in Russia for a uncertain period to find money for transit. Thus, the transit of the CIS migrants may occur, but the next transit stage will be out of migration statistics (later, that in ten days).

Migrants, having clear final points of destination and legally moving the transit stages, cover statistics of the transit or we see temporary migrations (tourism, education, work or private visits of the third countries through Russia). In such case, the trajectory of the transit will be determined by optimal combination of the duration / comfort / price of the root, and, probably, additional education purposes of a migrant.

\subsection{Acknowledgments and Legal Responsibility}

Paper is prepared in the frameworks of the President's Grant for state support of the leading scientific schools YI-6535.2018.6 "Social risks and security in conditions of transformation of migration processes in the Russ-an-Asian borderlands" (2018-2019). 


\section{8th International Conference on Humanities, Psychology and Social Science \\ October 19-21, 2018 Munich, Germany}

\section{References}

Papadopoulou-Kourkoula, A. (2008). Transit Migration. Retrieved from http://dx.doi.org/10.1057/9780230583801 (accessed June, 2018).

Düvell, F. (2006). Europäische und internationale Migration, Hamburg: Lit.

Maksimova, S. G., Omel'chenko, D. A., Noyanzina, O. E., et. al, (2016). Grazhdanskaya i ehtnicheskaya identichnost' naseleniya prigranichnyh regionov Rossii: monografiya. Barnaul: Izd-vo: OOO «Tipografiya Triada».

Düvell, F., Pastore, F., Haas, H. de, and Molodikova, I. (2009). Paper by results of the conference, based on results of 26 experts in 10 countries. Retrieved from http://www.compas.ox.ac.uk/events/past_conferences_events.shtml (Accessed June, 2018).

Trofimova, T. I. (2010). Fenomen tranzitnoj migracii. Izvestiya IGEHA. № 5 (73).

Radaev, V. (2013). Does Competition Eliminate Social Ties?: The Case of the Russian Retail Market // Polish Sociological Review. Vol. 13. No. 1. P. 63-86.

Castagnone, E. (2011). Transit migration: a piece of the complex mobility puzzle. The case of Senegalese migration, Cahiers de l'Urmis [Online], 13 October 2011. Retrieved from http://urmis.revues.org/927 (accessed June, 2018).

Farny, E. M. (2014). The Concept of Transit Migration. Contemporary migratory processes in the Saharan transition zone. An essay submitted in partial fulfillment of the requirements for the degree Bachelor of Arts in Social and Cultural Anthropology.

March 2014. Department of Social and Cultural Anthropology. University of Vienna.

Inter-Parliamentary Union. (2005). Migration and development. Geneva: IPU.

Papadopoulou, A. (2005). Exploring the asylum-migration nexus: a case study of transit migrants in Europe. Global Migration Perspectives No. 23. Geneva: Global Commission on International Migration.

Roman, H. (2006) Transit Migration in Egypt. CARIM research report. Florence: European University Institute.

Natural movement of population of the Russian Federation. Retrieved from http://www.gks.ru/wps/wcm/connect/rosstat_main/rosstat/ru/statistics/publications/catal og/doc_1140096846203 (Accessed June, 2018). 
October 19-21, 2018 Munich, Germany

Population and migration in the Russian Federation. Retrieved from http://www.gks.ru/wps/wcm/connect/rosstat_main/rosstat/ru/statistics/publications/catal og/doc_1140096034906 (Accessed June, 2018).

Data of the All-Russian Population census. (2010). Retrieved from http://www.gks.ru/free_doc/new_site/perepis2010/croc/perepis_itogi1612.htm (Accessed June, 2018). 